\title{
Jenis dan Populasi Serangga Hama pada Pertumbuhan dan Perkembangan Beberapa Varietas Tomat (Lycopersicum esculentum Mill.) (Insect Pest Species and Population on the Growth and Development of Some Tomatoes (Lycopersicum esculentum Mill.) Varieties)
}

\author{
Meisye Paruntu1)*, Odi Pinontoan ${ }^{1)}$, Eva Mamahit1) \\ 1) Program Studi Entomologi, Pasca Sarjana Universitas Sam Ratulangi, Kampus \\ UNSRAT Manado 95115 \\ *Email korespondensi: m_paruntu@yahoo.com
}

Diterima 31 Januari 2016, diterima untuk dipublikasikan 24 Februari 2016

\begin{abstract}
Abstrak
Penelitian yang dilaksanakan di desa Wailan Kecamatan Tomohon Selatan Kota Tomohon bertujuan untuk mengevaluasi gejala serangan, jenis-jenis dan populasi serangga hama dan pada beberapa varietas tomat yang ditanam dengan dan tanpa mulsa plastik hitam perak serta pola tanaman tunggal dan ganda. Percobaan faktorial dalam Rancangan Acak Kelompok (RAK) terdiri dari 3 faktor perlakuan, yaitu 1) varietas tomat (Warani/V1, Permata/V2, Sakura/ V3, Tirana/V4, Fortuna/V5); 2) jenis mulsa (tanpa mulsa/MO, mulsa plastik hitam perak/M1); 3) pola tanam (pola tanam tunggal/PTT dan pola tanam ganda/PTG). Hasil penelitian menunjukkan serangga hama yang ditemukan pada kombinasi perlakuan varietas, dengan atau tanpa mulsa plastik perak hitam, dan pola tanam tunggal dan ganda adalah Nesidiocoris tenuis, Liriomyza sativae, Acrida turita $L$., Aphis sp., Bemisia tabaci, Helicoverpa armigera, dan Nezara viridula L. Rataan populasi $\mathrm{N}$. tenuis yang tertinggi terdapat pada kombinasi perlakuan V3MOPTG (5,63 ekor/tanaman) dan yang terendah pada kombinasi V3M1PTT (0,78 ekor/tanaman). Rataan populasi L. sativae yang tertinggi pada kombinasi perlakuan V5M1PTG (2,35 ekor/tanaman) dan yang terendah pada V3M1PTT (0,54 ekor/tanaman).

Kata kunci: mulsa, pola tanam, serangga hama, tomat
\end{abstract}

\begin{abstract}
The study that was conducted in the village Wailan South Tomohon, Tomohon sub district aimed to evaluate the symptoms of the attack, the kind and the population of insect pests in several tomato varieties grown with and without silver black plastic mulch, as well as single and double cropping pattern. The factorial randomized block design consisted of 3 treatment factors, i.e. 1) tomato varieties (Warani/V1, Gem/V2, Sakura/V3, Tirana/V4, Fortuna/V5); 2) the mulch type (without mulch/MO, silver black plastic mulch/M1); 3) planting pattern (single cropping pattern/PTT, double cropping pattern/PTG). The results showed that pests type found in the treatment combination of varieties, with or without the silver black plastic mulch, and single and double cropping pattern were Nesidiocoris tenuis, Liriomyza sativae, Acrida turita L., Aphis sp., Bemisia tabaci, Helicoverpa armigera, and Nezara viridula L. The highest population of $\mathrm{N}$. tenuis insect pest was observed in the V3MOPTG treatment (5.63 insects / plant) and the lowest was in the V3M1PTT treatment (0.78 insects / plant). The highest population of $L$. sativae was obderved ini the V5M1PTG treatment (2.35 insects / plant) and the lowest was inn the V3M1PTT (0.54 insects / plant).

Kata kunci: cropping pattern, insect pest, mulch, tomato
\end{abstract}




\section{PENDAHULUAN}

Tanaman

tomat

(Lycopersicum esculentum Mill.) merupakan salah satu jenis tanaman hortikultura utama yang berasal dari Amerika Latin seperti Peru, Ekuador dan Meksiko dan kemudian menyebar keseluruh dunia (Ashari 1995). Lycopersicon esculentum pertama kali didomestikasi oleh bangsa asli Amerika Selatan. Tomat hasil kultivasi domestik memiliki bentuk dan ukuran buah yang bervariasi, sedangkan tomat tipe liar hanya memiliki sedikit variasi bentuk dan ukuran buah (Budiman 2008).

Tanaman tomat di Indonesia dapat dibudidayakan secara meluas mulai dari dataran rendah $(\leq 199 \mathrm{~m}$ $\mathrm{dpl}$ ), dataran medium rendah (200$449 \mathrm{~m} \mathrm{dpl}$ ), dataran medium tinggi (450 -699 m dpl) sampai dataran tinggi ( $\geq 700 \mathrm{~m} \mathrm{dpl}$ ) (Cahyono, 1989, 2003). Rukmana (1995) menyatakan bahwa pengembangan budidaya tanaman tomat di Indonesia telah meluas dan sentra produksi terdapat di Jawa Barat $(10,127$ ha), Bengkulu (4,602 ha), Sulawesi Selatan $(4,176$ ha), Sulawesi Utara (3,041 ha), Sumatera Utara (3,080 ha) dan Jawa Timur (2,608 ha).

Buah tomat dapat digunakan untuk makanan segar, bumbu masakan, obat untuk penyakit tertentu, sebagai minuman segar, sumber vitamin dan mineral. Kandungan vitamin pada buah tomat terutama vitamin A, B, dan C, karbohidrat, protein, lemak dan kalori (Paembonan 2003). Tomat menempati urutan pertama dalam skala prioritas penelitian pengembangan hortikultura di Indonesia (Cahyono 2003). Salah satu kendala utama dalam pengembangan dan produksi tanaman tomat adalah adanya organisme pengganggu tanaman (OPT) tomat, antara lain penggorok daun (Lyriomyza spp.), ulat penggerek bunga dan buah
(Helicoverpa armigera Hubn.), Aphis hijau (Myzus persicae Sulz.), thrips (Thrips tabaci Lind.), ulat grayak (Spodoptera litura), belalang pemakan daun (Valanga sp.), ulat pemakan daun Chrysodeixis sp. dan lalat buah (Bactrocera sp.) (Kalshoven 1981, Manoi 2010, Rauf et al. 2000, Arno et al. 2003).

Penggunaan varietas unggul tanaman tomat yang tahan terhadap serangan OPT akan meningkatkan produksi. Selain itu penggunaan komponen mulsa sintetis seperti mulsa plastik hitam perak dapat menolak serangga tertentu, mengendalikan patogen dan gulma, memodifikasi suhu tanah, mengurangi penguapan, mengendalikan pencucian unsur hara, meningkatkan dan memperbaiki kualitas produk panen (Vos 1994). Kombinasi penggunaan mulsa plastik dengan pola tanaman tunggal maupun ganda pada tanaman tomat menguntungkan dari aspek produksi dan pengelolaan OPT tomat. Atas dasar ini maka perlu dilakukan penelitian untuk mengevaluasi gejala serangan, jenis-jenis dan populasi serangga hama dan pada beberapa varietas tomat yang ditanam dengan dan tanpa mulsa plastik hitam perak serta pola tanaman tunggal dan ganda.

\section{METODE PENELITIAN}

Penelitian dilaksanakan di desa Wailan Kecamatan Tomohon Selatan Kota Tomohon pada Agustus-Desember 2014. Penelitian menggunakan Rancangan Acak Kelompok (RAK) Faktorial yang terdiri dari 3 faktor perlakuan, yaitu 1) varietas tomat (Warani/V1, Permata/V2, Sakura/ V3, Tirana/V4, Fortuna/V5); 2) jenis mulsa (tanpa mulsa/MO, mulsa plastik hitam perak/M1); 3) pola tanam (pola tanam tunggal/PTT dan pola tanam ganda/PTG). Tahap penelitian 
meliputi persemaian, penanaman, pemasangan ajir dan pengairan, pemeliharaan serta panen. Variabel pengamatan ialah gejala serangan dan jenis serangga hama akan diamati dan dideskripsikan sesuai jenis dan kerusakan yang terjadi pada bagian daun, batang, bunga dan buah tanaman tomat di lapangan setelah tanaman berumur 3 minggu setelah tanam (MST) sampai tanaman $14 \mathrm{MST}$, dengan interval 1 minggu. Lima rumpun tanaman diambil secara acak untuk diamati populasi serangga hama yang menyerang tanaman tomat. Data dianalisis dengan sidik ragam (ANOVA) dan dilanjutkan dengan uji BNT 0.05 jika terdapat perbedaan.

\section{HASIL DAN PEMBAHASAN Jenis Serangga}

Pengamatan terhadap jenis serangga hama kombinasi beberapa varitas tanaman Tomat (Lycopersicum esculentum Mill.) yang ditanam dengan dan tanpa penggunaan mulsa plastik perak hitam serta pola tanaman tunggal dan ganda, setelah diidentifikasi maka ditemukan beberapa serangga hama penting seperti terlihat pada Tabel 1.

Hasil penelitian yang dilakukan sejak pengamatan pertama pada umur tanaman 3 minggu sesudah tanaman (MST) sampai pada pengamatan umur tanaman 14 MST pada seluruh kombinasi perlakuan ditemukan tujuh jenis serangga hama penting pada tanaman tomat.

\section{Nesidiocoris tenuis (Miridae : Hemiptera)}

Kepik hijau kecoklatan ini memiliki sayap sempurna dan panjang tubuh 2,5-3,5 mm. Empat garis hitam dengan warna tubuh hijau tua pada toraks dan abdomen (Gambar 1).

\section{Acrida turita L. (Acrididae : Orthoptera)}

Serangga dewasa berwarna hijau daun dengan kepala memanjang dan antena yang cukup panjang. Panjang tubuh berkisar 3,8 - 7,5 cm dan serangga betina lebih besar dengan serangga jantan (Gambar 2).

Tabel 1. Jenis-Jenis Serangga Hama pada Tahap Perkembangan Kombinasi Beberapa Varitas Tanaman Tomat dengan dan Tanpa Mulsa Plastik serta Pola Tanaman Tunggal dan Ganda

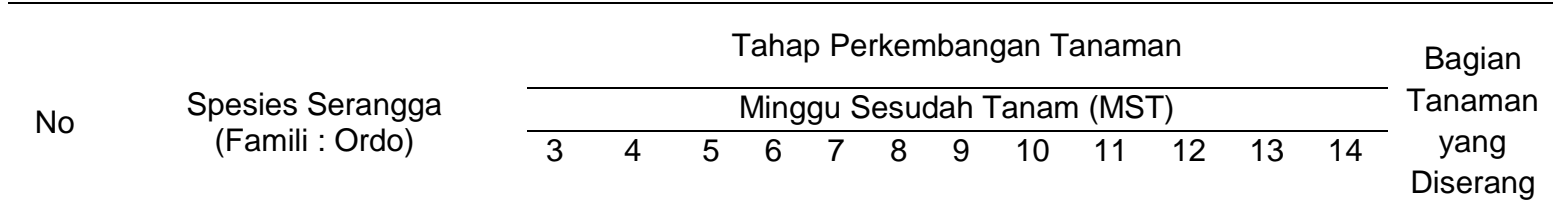

\begin{tabular}{|c|c|c|c|c|c|c|c|c|c|c|c|c|c|c|}
\hline 1. & $\begin{array}{l}\text { Nesidiocoris tenuis } \\
\text { (Hemiptera:Miridae) }\end{array}$ & $\sqrt{ }$ & $\sqrt{ }$ & $\sqrt{ }$ & $\sqrt{ }$ & $\sqrt{ }$ & $\sqrt{ }$ & $\sqrt{ }$ & $\sqrt{ }$ & $\sqrt{ }$ & $\sqrt{ }$ & $\sqrt{ }$ & $\sqrt{ }$ & $\begin{array}{l}\text { Daun/ } \\
\text { pucuk }\end{array}$ \\
\hline 2. & $\begin{array}{l}\text { Acrida turita (L.) } \\
\text { (Acrididae : Orthoptera) }\end{array}$ & $x$ & $\sqrt{ }$ & $\sqrt{ }$ & $\sqrt{ }$ & $\sqrt{ }$ & $\sqrt{ }$ & $\sqrt{ }$ & $\sqrt{ }$ & $\sqrt{ }$ & $\sqrt{ }$ & $\sqrt{ }$ & $\sqrt{ }$ & Daun \\
\hline 3. & $\begin{array}{l}\text { Aphis sp } \\
\text { (Aphididae :Acari) }\end{array}$ & $x$ & $x$ & $\sqrt{ }$ & $\sqrt{ }$ & $\sqrt{ }$ & $\sqrt{ }$ & $\sqrt{ }$ & $\sqrt{ }$ & $\sqrt{ }$ & $\sqrt{ }$ & $\sqrt{ }$ & $\sqrt{ }$ & Daun \\
\hline 4. & $\begin{array}{l}\text { Liriomyza sativae } \\
\text { (Diptera:Agromyzidae) }\end{array}$ & $\sqrt{ }$ & $\sqrt{ }$ & $\sqrt{ }$ & $\sqrt{ }$ & $\sqrt{ }$ & $\sqrt{ }$ & $\sqrt{ }$ & $\sqrt{ }$ & $\sqrt{ }$ & $\sqrt{ }$ & $\sqrt{ }$ & $\sqrt{ }$ & Daun \\
\hline 5. & $\begin{array}{l}\text { Bemisia tabaci } \\
\text { (Hemiptera:Aleyrodidae) }\end{array}$ & $x$ & $x$ & $\sqrt{ }$ & $\sqrt{ }$ & $\sqrt{ }$ & $\sqrt{ }$ & $\sqrt{ }$ & $\sqrt{ }$ & $\sqrt{ }$ & $\sqrt{ }$ & $\sqrt{ }$ & $\sqrt{ }$ & Daun \\
\hline 6. & $\begin{array}{l}\text { Helicoverpa armigera } \\
\text { (Lepidoptera:Noctuidae) }\end{array}$ & $X$ & $X$ & $X$ & $x$ & $X$ & $\sqrt{ }$ & $\sqrt{ }$ & $\sqrt{ }$ & $\sqrt{ }$ & $\sqrt{ }$ & $\sqrt{ }$ & $\sqrt{ }$ & $\begin{array}{l}\text { Buah/ } \\
\text { Pucuk }\end{array}$ \\
\hline 7. & $\begin{array}{l}\text { Nezara viridula L. } \\
\text { (Hemiptera:Pentatomidae) }\end{array}$ & $x$ & $X$ & $x$ & $\sqrt{ }$ & $\sqrt{ }$ & $\sqrt{ }$ & $\sqrt{ }$ & $\sqrt{ }$ & $\sqrt{ }$ & $\sqrt{ }$ & $\sqrt{ }$ & $\sqrt{ }$ & $\begin{array}{l}\text { Daun } \\
\text { dan buah }\end{array}$ \\
\hline
\end{tabular}




\section{Aphis sp. (Aphididae : Homoptera)}

Kutu ini ada yang bersayap dan ada yang tidak bersayap. Panjang tubuh bersayap antara 22,5 mm, kepala dan toraksnya berwarna coklat sampai hitam dan abdomennya hijau kekuningkuningan. Ukuran antena sepanjang badannya. Panjang tubuh kutu yang tidak bersayap antara 1,8-2,3 mm dan berwarna hijau kekuningkuningan (Gambar 3).

\section{Liriomyza sativae Blancard (Agromyzidae : Diptera)}

Serangga dewasa akan muncul dari selongsong pupa pada pagi hari. Imago berukuran kecil dengan panjang sekitar 1,5 $\mathrm{mm}$. Tubuh berwarna hitam kecoklatan dan terdapat bintik kuning. Kepala berwarna kuning dan abdomen berwarna kelabu dengan bintik kuning. Gejala serangan L. sativae adalah ketika telur menetas pada bagian bawah epidermis daun maka larva-larva muda akan menggorok daun sehingga membentuk terowongan yang berkelok-kelok tidak beraturan seperti spiral (Gambar 4).

\section{Bemisia tabaci (Genn)}

Serangga dewasa dengan sayap jernih, ditutupi lapisan lilin yang bertepung. Ukuran tubuhnya berkisar 1-1,5 mm. Serangga dewasa biasanya hidup berkelompok dalam jumlah yang banyak, dan bila tersentuh akan beterbangan seperti kabut, sehingga disebut kebul putih (Gambar 5).

\section{Helicoverpa \\ (Noctuidae : Lepidoptera)}

Larva yang baru menetas berukuran $1,44 \mathrm{~mm}$ dan akan memakan daun tomat dan setelah instar ke-3 mulai menyerang buah tomat. Larva muda tertutup oleh banyak kutil dan bulu. Warna tubuh larva bervariasi dari hijau kekuningan, coklat tua, coklat muda, ungu, hijau atau agak hitam. Larva muda berwarna putih kekuningan dengan kepala berwarna hitam. Panjang tubuh larva dewasa 34,5 mm (Gambar 6).

\section{Kepik Hijau Nezara viridula (Pantatomidae : Hemiptera)}

Ciri-ciri kepik dewasa berwarna hijau, berbentuk segi lima seperti perisai, panjang tubuh sekitar $1 \mathrm{~cm}$ dan kepalanya bersungut. Ada juga yg berwarna kuning kehijauan. Pada bagian punggungnya terdapat 3 bintik berwarna hijau (Gambar 7).

\section{Populasi Serangga Hama}

Populasi serangga hama
yang berpengaruh signifikan
terhadap pertumbuhan dan
perkembangan tanaman tomat
adalah N. tenuis dan L. sativae.
Serangga $N$. tenuis ditemukan pada semua kombinasi perlakuan saat tanaman berumur 3-14 MST. Hasil ANOVA menunjukkan bahwa hanya faktor pola tanam (PT) berpengaruh sangat nyata terhadap populasi $N$. tenuis. Dua taraf pola tanam yaitu pola tanaman tunggal (PTT) dan pola tanam ganda (PTG) memberikan respon yang berbeda terhadap populasi N. tenuis (Gambar 8). Populasi $N$. tenuis tertinggi pada kombinasi perlakuan V3MOPTG (varietas Sakura tanpa mulsa plastik dengan pola tanam ganda), yakni 5,63 ekor, sedangkan populasi terendah terdapat pada kombinasi perlakuan V3M1PTT (varietas Sakura dengan mulsa plastik dan pola tanam tunggal), yakni 0,78 ekor. Populasi N. tenuis relatif lebih rendah ketika kombinasi perlakuan bertautan pada pola tanam tunggal, tetapi sebaliknya pada tautan pola tanam ganda rataan populasi lebih tinggi. Hal ini disebabkan karena jumlah daun pada pola tanam ganda lebih banyak dibandingkan dengan pola tanaman tunggal, sehingga ketersediaan tempat meletakkan telur, makan dan nutrisi lebih besar. Ketersedian makanan merupakan faktor penting bagi serangga, karena ketersediaan makanan yang cukup 


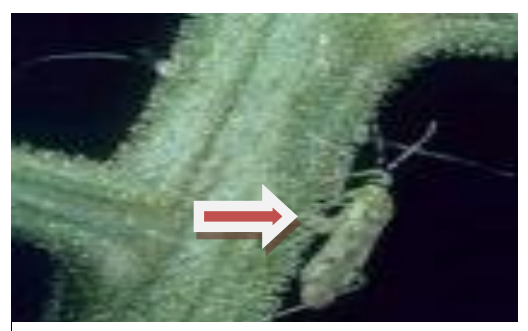

Gambar 1. N. tenuis

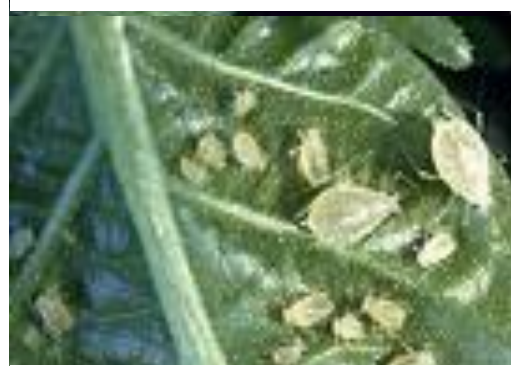

Gambar 3. Aphis sp.

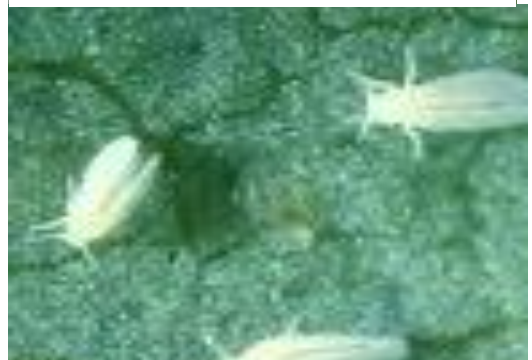

Gambar 5. B. tabaci

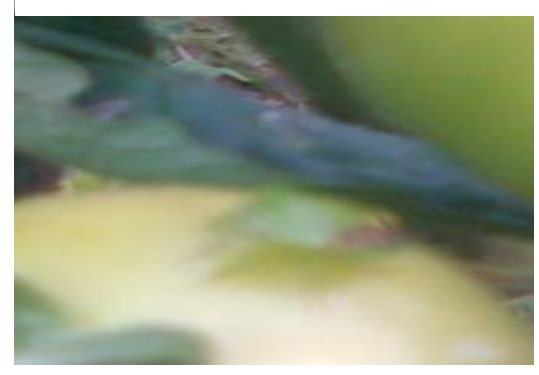

Gambar 7. N. viridula

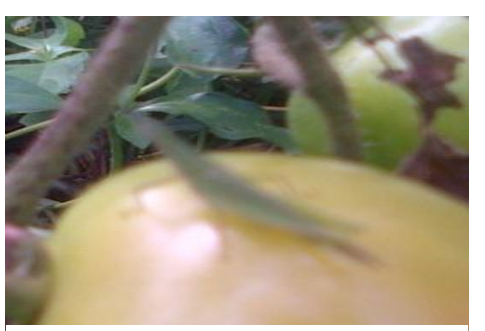

Gambar 2. A. turita (L.)

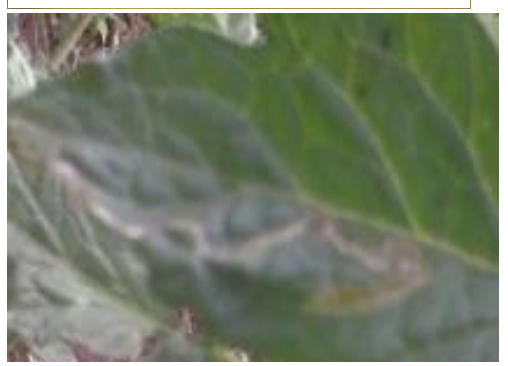

Gambar 4. Gejala serangan L. sativae

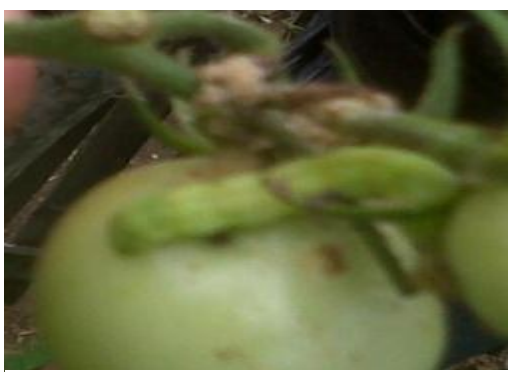

Gambar 6. H. armigera akan membantu perkembangan populasi (Untung 1993, Calvo et.al 2008). Populasi serangga akan cepat meningkat jika daun tanaman sebagai sumber makanan utama berlimpah (Jumar 2000).

L. sativae ditemukan pada seluruh kombinasi perlakuan pada saat tanaman berumur 3-14 MST. Hasil ANOVA menunjukan bahwa faktor varietas (V), mulsa plastik (M), pola tanam (PT), interaksi VM, interaksi VPT, interaksi MPT dan interaksi VMPT berpengaruh sangat nyata terhadap populasi $L$. sativae. Uji Lanjut BNT 0.05 hanya dilakukan pada interaksi kombinasi perlakuan VMPT dan hasilnya dapat dilihat pada Tabel 2. Populasi L. sativae tertinggi adalah pada perlakuan V5M1PTG (varietas Fortuna dengan mulsa plastik pada pola tanam ganda), sedangkan yang terendah adalah perlakuan V3M1PTT (varietas Sakura dengan mulsa plastik pada pola tanam tunggal). 


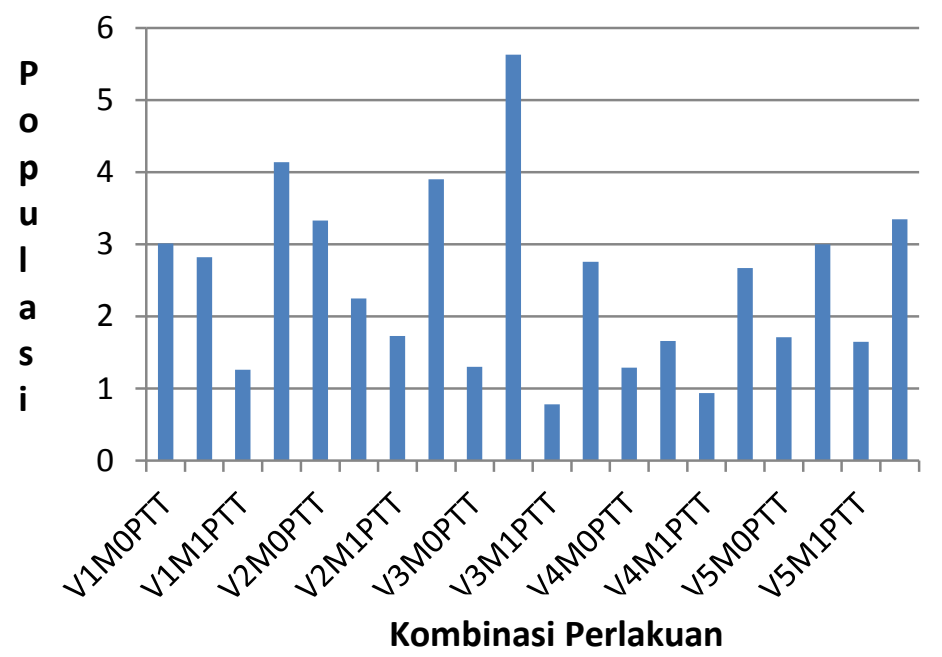

Gambar 8. Rata-rata populasi serangga N. tenuis pada kombinasi perlakuan varitas (V), mulsa plastik (M) dan pola tanam (PT) pada 3-14 MST

Tabel 2. Rata-rata Populasi Serangga L. sativae pertanaman sesuai kombinasi perlakuan varietas tomat, dengan dan tanpa mulsa dan dengan pola tanam tunggal dan ganda

\begin{tabular}{|c|c|c|}
\hline Perlakuan & Rataan Populasi & Notasi \\
\hline V1M0PTT & 1.44 & g \\
\hline VIMOPTG & 0.83 & $\mathrm{bc}$ \\
\hline V1M1PTT & 0.90 & $\mathrm{bc}$ \\
\hline VIM1PTG & 1.43 & g \\
\hline V2M0PTT & 1.40 & $g$ \\
\hline V2M0PTG & 0.92 & $\mathrm{~cd}$ \\
\hline V2M1PTT & 0.86 & $\mathrm{bc}$ \\
\hline V2M1PTG & 1.88 & $\mathrm{~h}$ \\
\hline V3M0PTT & 0.79 & $\mathrm{bc}$ \\
\hline V3M0PTG & 0.58 & a \\
\hline V3M1PTT & 0.54 & a \\
\hline V3M1PTG & 1.05 & def \\
\hline V4M0PTT & 0.77 & $\mathrm{~b}$ \\
\hline V4MOPTG & 0.60 & a \\
\hline V4M1PTT & 0.58 & a \\
\hline V4M1PTG & 1.01 & cde \\
\hline V5M0PTT & 1.51 & $g$ \\
\hline V5M0PTG & 1.13 & ef \\
\hline V5M1PTT & 1.16 & $f$ \\
\hline V5M1PTG & 2.35 & 1 \\
\hline
\end{tabular}

Keterangan : Angka yang diikuti oleh huruf yang sama tidak berbeda nyata (BNT $0,05=0,14$ ) 


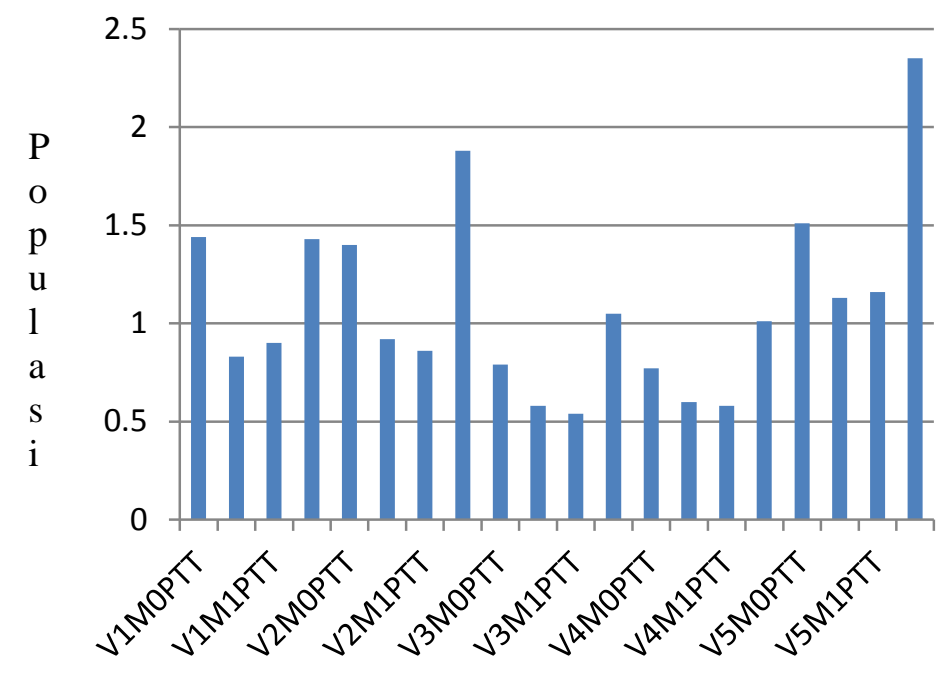

Kombinasi Perlakuan

Gambar 9. Rata-rata populasi serangga $L$. sativea pada kombinasi perlakuan varitas (V), mulsa plastik (M) dan pola tanam (PT)

Populasi L. sativae pada areal pertanaman tomat di lapangan mulai berkembang saat tanaman tomat berumur 3 MST dan terus meningkat sampai 7 dan 8 MST dan akhirnya menurun sampai 12 MST. Populasi L. sativae (Gambar 9) tertinggi pada kombinasi perlakuan V5M1PTG (2,35 ekor), sedangkan populasi terendah pada perlakuan V3M1PTT (0,54 ekor). Populasi tertinggi diamati pada pada kombinasi perlakuan dengan varietas Fortuna dengan mulsa plastik pada pola tanam ganda dan varietas Permata dengan mulsa plastik pada pola tanam ganda, sedangkan populasi terendah terdapat pada kombinasi perlakuan varietas Sakura dengan mulsa plastik pada pola tanam tunggal. Perbedaan populasi $L$. sativae diduga disebabkan oleh kombinasi perlakuan verietas, mulsa plastik dan pola tanam, ketersedian makanan, adanya musuh alami, dan resistensi tanaman terhadap hama. Tersedianya daun tanaman bagi $L$. sativae sebagai tempat berkembangnya stadia pradewasa menunjang perkembangan populasinya. Perkembangan $L$. sativae di lapang sangat dipengaruhi oleh tersedianya daun tanaman tomat baik yang berkualitas. Serangan penyakit bercak coklat pada daun segar mengakibatkan perkembangan serangga pengorok daun akan terbatas dan populasinya menurun (Manoi 2010). Makanan juga merupakan faktor penting bagi serangga (Untung 1993). Musuh alami terutama parasitoid Hemiptarsenus varicornis (Hymenoptera: Eulopidae) menurunkan populasi $L$. sativae (Sembel 2014, Manoi 2010). Resistensi tanaman juga dapat mempengaruhi pemilihan inang oleh serangga hama seperti resistensi morfologis dan kimiawi (Sunarjo 1991). Rendahnya populasi $L$. sativae yang menyerang varietas tomat menunjukkan varietas tersebut lebih resisten terhadapan serangan hama tersebut.

\section{KESIMPULAN}

Hasil penelitian menunjukkan serangga hama yang ditemukan 
pada kombinasi perlakuan varietas, dengan atau tanpa mulsa plastik perak hitam, dan pola tanam tunggal dan ganda adalah Nesidiocoris tenuis, Liriomyza sativae, Acrida turita L., Aphis sp., Bemisia tabaci, Helicoverpa armigera, dan Nezara viridula L. Rata-rata populasi $N$. tenuis yang tertinggi terdapat pada kombinasi perlakuan V3M0PTG (5,63 ekor/tanaman) dan yang terendah pada kombinasi V3M1PTT $(0,78$ ekor/tanaman). Rata-rata populasi L. sativae yang tertinggi pada kombinasi perlakuan V5M1PTG (2,35 ekor/tanaman) dan yang terendah pada V3M1PTT $(0,54$ ekor/tanaman).

DAFTAR PUSTAKA

Arno J, Castane J, Reudavets R, Gabara (2003) Risk of damage to tomato crops by the generalist zoophytophagous predator Nesidiocoris tenuis (Reuter)

Hemiptera:Miridae).http:// www.ncbi.nml.nih.gov/pub med/1966476? ordinalpos $=$ 1\&itool+EntrezSystem2.P entrez.Pubmed.Pubmed Result. Diakses tanggal 16 Juni 2015

Ashari S (1995) Hortikutura aspek budidaya. Penerbit Universitas Indonesia (UIPress). Jakarta

Budiman A (2008) Biologi dan ekologi Cyrtopeltis tenuis IHemiptera:Miridae) pada tanaman tomat. Tesis. Pascasarjana Universitas Sam Ratulangi Manado

Cahyono B (1989) Tomat. Budidaya dan Analisis Usaha Tani. Kanisius Yogyakarta (2003) Tomat budidaya dan analisis usaha tani. Kanisius. Yogyakarta

Calvo J, Bolckmans K, Stansly PA, Urbaneja A (2008) Predation by Nesidiocoris tenuis on
Bemisia tabaci and injury to tomato. International Organization for Biological Control (IOBC). Almeria, Spanyol

Jumar (2002) Entomologi pertanian. Penerbit Rineka Cipta. Jakarta

Kalshoven LGE (1981) Pest of crops in Indonesia. PT. Ichtiar Baru-Van Hoeve. Jakarta

Manoi TB (2010) Jenis dan populasi serangga dengan dan tanpa penyemprotan pestisida Pada beberapa galur/varietas tomat (Lycopersicum esculentum Mill.)

Paembonan A (2003) Budidaya tomat di pertanian organik. Yayasan Bina Sarana Bakti Cisarua. IPB. Bogor

Rauf A, Shepard BM, Johnson MW (2000) Leafminars in vegetables, ornamental plants and weeds in Indonesia: Survey of host crops, species composition and parasitoids. International Journal of Pest Management. Taylor \& Francis Ltd

Rukmana R (1995) Tomat dan cherry. Penerbit Kanisius. Jakarta

Sembel DT (2014) Seranggaserangga hama tanaman pangan, umbi \& sayuran. Bayumedia Publishing Anggota IKAPI. Malang.

Sunarjo PI (1991) Biologi dan ekologi Serangga. Pusat Antar Universitas Bidang Ilmu Hayati-ITB. Bandung.

Untung K (1993) Pengantar pengelolaan hama terpadu. Gajah Mada University Press. Yoyakarta

Vos JGM (1994) Pengelolaan tanaman terpadu pada tanaman cabai (Capsicum spp.) dataran rendah Tropik. Balai Penelitian Hortikultura. Lembang 
